\title{
PENGGUNAAN EMODUL INTERAKTIF MENGGUNAKAN METODE DISCOVERY LEARNING UNTUK MENINGKATKAN PERFORMA AKADEMIK SISWA PADA MATA PELAJARAN BAHASA INGGRIS DI KELAS X MIPA 7 SMAN 1 GARUT
}

\author{
RINA AGUSTINA \\ SMA Negeri 1 Garut, Jawa Barat \\ e-mail : rina160871@gmail.com
}

\begin{abstract}
ABSTRAK
Penelitian ini bertujuan untuk meningkatkan keterlibatan siswa dalam Pembelajaran Bahasa Inggris dengan menggunakan Emodul Interaktif dengan metode Discovery learning. Subjek penelitian terdiri dari 32 siswa SMA dengan fokus pada siswa Berprestasi Rendah (LA) dan Berprestasi Tinggi (HA). Penelitian ini merupakan Penelitian Tindakan Kelas (PTK) dengan 3 Siklus. Prosedur penelitian meliputi tahap refleksi, perencanaan pelaksanaan tindakan dan observasi. Behavioral Engagement (BE) Data diperoleh melalui observasi, data lain berupa Psychologycal Engagement (PE) dan Cognitive Engagement (CE) diperoleh melalui angket student engagement berdasarkan Student engagement Instrument (SEI). Hasil penelitian menunjukan bahwa penggunaan E Modul Interaktif dengan metode Discovery Learning dapat meningkatkan keterlibatan siswa dalam pembelajaran Bahasa Inggris, khususnya pada materi Past Tense vs Present Perfect Tense. Persentase rata-rata semua aspek BE yang diamati pada siswa LA sebelum diberikan perlakuan. Siklus I, Siklus II dan Siklus III masing-masing sebesar $13,7 \%, 35,24 \%, 48,26 \%$ dan 64, $24 \& \%$. Sedangkan hasil BE siswa HA sebelum perlakuan diberikan. Siklus I, Siklus II, dan Siklus III masing-masing sebesar 22,2\%, 48,97\%, 56,6\% dan $64,76 \%$. Hasil PE siswa HA sebelum diberikan perlakuan siklus III meningkat dari 3,75\%, hasil LA siswa meningkat sebelum diberikan perlakuan terhadap siklus III yaitu 2,94\% sedangkan pada siswa HA meningkat 2,95. \%.
\end{abstract}

Kata Kunci: Penelitian Tindakan Kelas (PTK), EModul Interaktif dengan metode Discovery Learning, Keterlibatan siswa, Pembelajaran Bahasa Inggris

\begin{abstract}
This study aims to increase student involvement in learning English by using Interactive $E$ module using the Discovery learning method. The research subjects consisted of 32 high school students with a focus on Low Achieving (LA) and High Achieving (HA) students. This research is a Classroom Action Research (CAR) with 3 cycles. The research procedure includes the stage of reflection, planning the implementation of the action and observation. Behavioral Engagement (BE) Data were obtained through observation, other data in the form of Psychological Engagement (PE) and Cognitive Engagement (CE) were obtained through a student engagement questionnaire based on the Student Engagement Instrument (SEI. The results showed that the use of Interactive E module using Discovery Learning method can increase student involvement in learning English, especially in the material Past Tense vs Present Perfect Tense. Average percentage of all aspects of BE observed in LA students prior to treatment. Cycle I, Cycle II and Cycle III respectively 13.7\%, 35, 24\%, 48.26\% and 64, 24 $\& \%$. While the BE results of HA students before the treatment is given. Cycle I, Cycle II, and Cycle III respectively $22.2 \%, 48.97 \%, 56.6 \%$ and $64.76 \%$. The PE results of $H A$ students before being given treatment in cycle III increased from $3.75 \%$, the LA results of students increased before being given treatment in cycle III which was $2.94 \%$ while those of HA students increased 2.95. \%.
\end{abstract}

Keywords: Classroom Action Research (CAR), Interactive E module using Discovery Learning method, student involvement, English Language learning. 


\section{PENDAHULUAN}

Perkembangan Ilmu pengetahuan dan teknologi semakin mendorong pembaharuan dalam pemanfaatan hasil - hasil teknologi dalam proses pembelajaran. Belajar sebagai perubahan yang terjadi pada individu melalui pengalaman dan bukan karena pertumbuhan atau perkembangan tubuhnya atau karakteristik seseorang sejak lahir (Trianto:2011). Menurut Nurhayati (2011:93) proses pembelajaran merupakan upaya mengondisikan lingkungan agar terjadi kegiatan belajar. Dalam perannya sebagai fasilitator, guru memiliki peran penting agar mampu memfasilitasi pembelajaran yang mencapai target pencapaian kompetensi yang dikenal dengan kompetensi Abad 21.

Pembelajaran aktif merupakan pendekatan pembelajaran yang lebih banyak melibatkan aktivitas peserta didik dalam mengakses berbagai informasi dan pengetahuan untuk dibahas dan dikaji dalam proses pembelajaran di kelas sehingga mereka mendapatkan berbagai pengalaman yang dapat meningkatkan pemahaman dan kompetensinya. Lebih dari itu, pembelajaran aktif memungkinkan peserta didik mengembangkan kemampuan berpikir tingkat tinggi, seperti menganalisis dan menyintesis, serta melakukan penilaian terhadap berbagai peristiwa belajar, dan menerapkannya dalam kehidupan sehari hari. Pembelajaran aktif memiliki persamaan dengan model pembelajaran self discovery learning, yakni pembelajaran yang dilakukan oleh peserta didik untuk menemukan kesimpulan sendiri sehingga dapat dijadikan sebagai nilai baru yang dapat diimplementasikan dalam kehidupan sehari-hari. Dalam model pembelajaran aktif, guru lebih memposisikan dirinya sebagai fasilitator, yang bertugas memberikan kemudahan belajar (to facilitate of learning) kepada peserta didik. Peserta didik terlibat secara aktif dan banyak berperan dalam proses pembelajaran sedangkan guru lebih banyak memberikan arahan dan bimbingan, serta mengatur sirkulasi dan jalannya proses pembelajaran. Pembelajaran kreatif merupakan proses pembelajaran yang mengharuskan guru untuk dapat memotivasi dan memunculkan kreativitas peserta didik selama pembelajaran berlangsung, dengan menggunakan beberapa metode dan strategi yang bervariasi, misalnya, kerja kelompok, bermain peran, dan pemecahan masalah. Pembelajaran kreatif menuntut guru untuk mampu merangsang kreativitas peserta didik, baik dalam mengembangkan kecakapan berpikir maupun dalam melakukan suatu tindakan. Berpikir kreatif selalu dimulai dengan berpikir kritis, yakni menemukan dan melahirkan sesuatu yang sebelumnya tidak ada atau memperbaiki sesuatu. Berpikir kreatif harus dikembangkan dalam proses pembelajaran, agar peserta didik terbiasa untuk mengembangkan kreatifitasnya.

Menurut Fadly (2014: 166) media adalah komponen sumber belajar atau wahana fisik yang mengandung materi Instruksional di kalangan siswa yang dapat merangsang siswa untuk belajar. Media pembelajaran adalah sarana komunikasi yang digunakan untuk menyampaikan pesan atau bahan pembelajaran. Selain itu, media pembelajaran berguna untuk menarik minat siswa terhadap materi pembelajaran serta meningkatkan pemahaman siswa.

Berdasarkan hasil angket yang diberikan oleh peneliti kepada siswa kelas X SMAN 1 Garut, didapatkan data bahwa sekitar $75 \%$ siswa kelas $\mathrm{X}$ menilai penggunaan media pembelajaran belum bervariasi dan belum dapat memenuhi kebutuhan peserta didik yang memiliki bakat,minat dan kemampuan yang bervariasi di kelas. Hal ini dapat diasumsikan dari perolehan informasi yang menyatakan kebanyakan guru belum menggunakan media interaktif dalam pembelajaran. Ketersediaan referensi buku yang masih terbataspun menjadikan kendala bagi sebagian peserta didik yang ingin menambah referensi untuk materi pembelajaran yang sedang dipelajari. Berbagai macam sumber yang terdapat di Internetpun, tidak menjamin keinginan peserta didik untuk mau mengeksplorasi berbagai sumber internet tersebut tanpa adanya arahan yang jelas dari guru mata pelajaran di sekolah tempat siswa belajar.

Penelitian yang dilakukan oleh Irma dan Suci (2015) dengan judul Pengembangan ebook berbasis Android dengan pendekatan scientifik pada mata pelajaran Administrasi pajak kelas XII Akuntansi di SMK Negeri 2 Buduran. Hasil dari penelitian berupa Research and Development tersebut didapatkan hasil validitas yang sangat baik dari sisi validitas materi, bahasa, kelayakan dan respon peserta didik terhadap penggunaan emodul berbasis saintifik 
tersebut, namun emodul ini masih khusus bisa digunakan oleh guru mata pelajaran yang hanya berkaitan dengan materi khusus yaitu materi Pajak. Penelitian yang sudah dilakukan oleh Indrawati Wilujeng dan Sri Mulyaningsih (2013) dengan judul Pengembangan media ebook Interaktif melalui strategi Mind Mapping pada materi pokok listrik dinamis untuk SMA Kelas X.penelitian bentuk deskriptif kuantitatif dengan Desain penelitian 4 D inipun masih berfokus khusus pada pembelajaran Fisika dengan hasil uji kelayakan pada berbagai aspek validitas dengan kategori sangat baik untuk digunakan sebagai media pembelajaran.Penelitian yang dilakukan oleh Siti (2015) hasil dari penelitiannya yang berupa laporan Skripsi berjudul Pengembangan bahan ajar berbasis ebook menggunakan kvisoft flipbook maker untuk kelas VIII MTSN 2 Kota Cirebon, uji keefektifan produk menggunakan perhitungan dari hasil análisis uji Independent test sebesar 6,612 didapat kesimpulan bahwa siswa yang menggunakan bahan ajar berbasis ebook dengan kvisoft flipbook maker lebih efektif dibandingkan dengan siswa yang tidak menggunakan bahan ajar berbasis ebook dengan kvisoft flipbook maker . Penggunaannya sangat efektif khusus untuk pembelajaran mata pelajaran Matematika. Hasil beberapa penelitian tersebut yang memnekankan spesialisasi pada mata pelajaran tertentu, maka penulis merasa perlu untuk melakukan penelitian tentang Penggunaan emodul dalam pembelajaran Bahasa Inggris untuk peserta didik SMA.

Beranjak dari permasalahan tersebut di atas, maka peneliti merasa tertarik untuk melakukan penelitian dengan menggunakan media pembelajaran E Modul Interaktif meggunakan metode Discovery Learning pada materi 'Past Tense vs Present Perfect Tense', salah satu bagian materi yang harus dikuasai dalam mata pelajaran Bahasa Inggris.

\section{METODE PENELITIAN}

Penelitian Tindakan kelas ini dilaksanakan dengan menggunakan Model Lewin, yang mengembangkan model Action Research dalam sebuah sistem yang terdiri dari sub sistem input, transformation dan output .Pada tahap input diperoleh informasi bahwa siswa kelas $\mathrm{X}$ merasa bosan dan jenuh ketika mengikuti proses pembelajaran monoton yang berpusat pada guru. Guru terlihat kurang menggunakan media pembelajaran yang efektif untuk mennjang pembelajaran, hasil belajar siswa pada materi Past Tense vs Present Perfect Tense masih rendah yaitu dengan rata - rata nilai sebesar $65 \%$. Hasil dari studi pendahuluan ini kemudian dianalisis untuk dibuat hipotesis tindakan penelitian berupa penggunaan media pembelajaran berupa Emodul terkait materi tersebut. Proses Penelitian Tindakan Kelas dengan model Lewin ini tergambar pada Flow chart berikut ini;

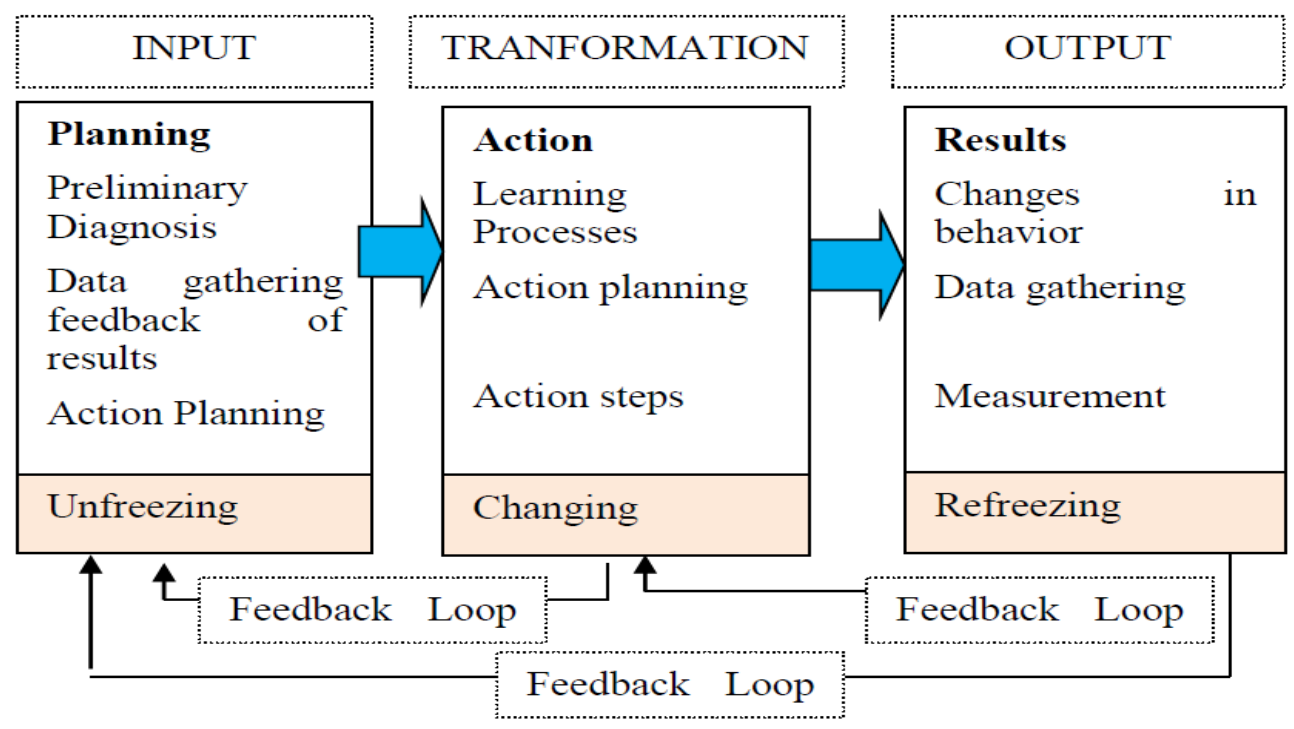

Gambar 1. Flow Chart. System Model of Action Research Process (Lewin : 1958). 
Pada tahap transformation, dilaksanakan tindakan yang telah dirancang, karena penelitian ini diterapkan di kelas, maka pelaksanaan tindakan diintegrasikan pada proses pembelajaran. Perubahan prilaku yang diharapkan berupa keterlibatan siswa secara aktif dan mandiri untuk mengakses pembelajaran terkait materi Past Tense vs Present perfect Tense ini kemudian diobservasi. Dari hasil observasi tersebut dapat disimpulkan rencana tindakan selanjutnya apakah penelitian perlu Feedback Loop A .Namun, observasi di Siklus I ini menggambarkan bahwa terdapat peningkatan keterlibatan keaktifan siswa dalm proses pembelajaran sebesar $5 \%$, namun karena peningkatan belum maksimal, maka diadakan pengkajian ulang dengan Loop Feedback A ini. Hasil Evaluasi pada peningkatan keterlibatan peran siswa ini perlu ditingkatkan dengan perencanaan tindakan berupa pemberian stimulus pada siswa yang mampu melaksanakan tugas emodul ini dengan baik, maka setelah diadakan Feedback Loop B ini didapatkan informasi bahwa peningkatan peran serta siswa semakin baik dengan hasil keterlibatan sebesar $75 \%$. Feed Back Loop c sejatinya sebagai umpan balik akhir yang digunakan sebagai penyempurnaan penelitian ini dan menguji hasil pemberian tindakan ini dengan memeberikan tes akhir kepada siswa.

Secara garis besar pada penelitian ini akan memaparkan secara garis besar hasil dari tahapan penelitian sebagai berikut : 1)Mengidentifikasi efektifitas penggunaan media pembelajaran berbentuk emodul Interaktif menggunakan metode Discovery Learning yang digunakan di kelas X Mipa 7 SMAN 1 Garut. 2).Mengetahui respon siswa terhadap Mata pelajaran Bahasa Inggris menggunakan emodul Interaktif menggunakan metode Discovery learning.

Instrumen digunakan untuk menggali informasi terkait keefektifan penggunaan emodul Interaktif tersebut bagi para siswa. Berikut ini penilaian dengan Skala Likert :

Tabel 1. Tabel Penilaian Skala Likert.

\begin{tabular}{|l|c|}
\hline KRITERIA & SKOR \\
\hline 'SANGAT BAIK' & 5 \\
\hline 'BAIK' & 4 \\
\hline 'SEDANG' & 3 \\
\hline 'TIDAK BAIK' & 2 \\
\hline 'SANGAT TIDAK BAIK' & 1 \\
\hline
\end{tabular}

Sumber : Ridwan (2013)

Dari skor di atas kemudian dianalisis dengan cara menghitung rata -rata jawaban dari setiap skor jawaban responden kemudian dipersentasikan

Persentase $=\underline{\text { Jumlah Skor Total }}$ X $100 \%$ Jumlah Skor Maksimum

Data angket respon peserta didik dianalisis menggunkan skala Gutman yaitu skala pengukuran dengan perolehan jawaban tegas seperti "ya-tidak" "benar - salah" "pernah -tidak pernah " dan lain sebagainya.

Tabel 2. Kriteria Penilaian Skala Gutman.

\begin{tabular}{|l|l|}
\hline Kriteria & skor \\
\hline "ya" & 1 \\
\hline "tidak' & 0 \\
\hline
\end{tabular}

Sumber : Ridwan (2013)

Dari skoring di atas kemudian dianalisis dengan cara sebagai berikut

Persentase $=$ Jumlah skor Total X $100 \%$

Jumlah skor maksimum 
Dari hasil persentase tersebut kemudian diperoleh kesimpulan mengenai pendapat peserta didik terhadap eModul Interaktif menggunakan metode Discovery learning setelah dianalisis dengan menggunakan Skala Likert dengan kriteria interpretasi skor sebagai berikut ;

Tabel 3. Kriteria Interpretasi Skor

\begin{tabular}{|l|l|}
\hline Persentase & Kriteria Interpretasi \\
\hline $0-20$ & Sangat Tidak Baik \\
\hline $21-40$ & Tidak Baik \\
\hline $41-60$ & Cukup Baik \\
\hline $61-80$ & Baik \\
\hline $81-100$ & Sangat baik \\
\hline
\end{tabular}

Sumber : Ridwan (2013)

Menurut tabel tersebut, maka eModul Interaktif menggunakan metode Discovery Learning pada materi Past Tense vs Present perfect Tense sangat baik jika rata -rata respon peserta didik persentase lebih dari $61 \%$.

\section{HASIL DAN PEMBAHASAN}

Penelitian ini berawal dari masalah dan potensi yang terdapat di SMA Negeri 1 Garut. Bahan ajar di sekolah masih berupa buku paket yang tersedia di perpustakaan sekolah dan penggunaan media pembelajaran di kelas oleh guru mata pelajaran masih berupa catatan di papan tulis (belum bervariasi) sehingga pelaksanaan proses belajar mengajar yang dilakukan di kelas terlihat monoton. Keterlibatan siswa dalam proses pembelajaranpun belum menunjukan partisipasi aktif. Siswa terlihat tidak antusias dan malas mengikuti pembelajaran. Hal ini menyebabkan kemandirian dan keaktifan peserta didik kurang karena pembelajaran masih berpusat pada guru. Sedangkan pada tujuan kurikulum 2013, pembelajaran berpusat pada peserta didik dan guru bertugas sebagai fasilitator proses pembelajaran. Hal ini kemudian ditambah dengan kondisi hasil rata rata Pre test yang diadakan sebelum pemberian tindakan yang menunjukan rata rata yang sangat tidak memuaskan yaitu dengan rata rata skor nilai pengetahuan sebesar 55 .

Menurut Khotib (2014: 8) bahan ajar merupakan bahan atau alat atau instrumen dalam proses pembelajaran yang di dalamnya terdapat materi pembelajaran yang disusun secara lengkap dan sistematis, dengan tujuan siswa dengan mudah memahami materi yang diajarkan. Potensi dalam Penelitian Tindakan Kelas ini yaitu Meningkatkan performa peserta didik Kelas X Mipa 7 SMA pada materi Past Tense vs Present Perfect Tense mata pelajaran Bahasa Inggris. Performa akademik yang dimaksud adalah Performa berupa Motivasi peserta didik dalam belajar ketika menggunakan emodul berbasis Discovery learning dan Hasil belajar berupa kemampuan peserta didik dalam menerapkan perbedaan penggunaan Past Tense vs Present Perfect Tense .Emodul yang digunakan berbasis Discovery learning dalam pembelajaran di kegiatan penelitian Tindakan kelas ini menggunakan perangkat elektronik berupa telepon selular berplatform Android yang dapat digunakan kapan saja dan di mana saja sehingga lebih memudahkan peserta didik dalam mengaakses materi pembelajaran dan latihan soal. Hal ini selaras dengan pernyataan Winters (Teodores : 2015 )"Mobile learning refers to any form of learning mediated through a mobile device, which can take place anywhere, anytime and at the convenience of the learners". Selain itu penggunaan Emodul ini diharapkan dapat membantu peserta didik dalam mempelajari materi yang kurang lengkap pada buku ajar. Penggunaan lay out yang baik dapat menambah motivasi peserta didik.

Selanjutnya peneliti melaksanakan pengamatan dan pencatatan aktivitas siswa melalui pemberian Angket keterlibatan siswa pada pembelajaran berdasarkan student engagement Instrument (SEI) (Grier Ried Apleton ,Rodriguez, Ganuza and Reschly : 2012) . Gambar 1 menunjukkan perbandingan BE siswa HA dan LA pada Pratindakan, Siklus I, siklus II dan Siklus III. Siswa HA menunjukkan angka 22,22 \% pada pratindakan kemudian mengalami 
kenaikan menjadi 44,97\% pada Siklus I. Pada siklus II kembali mengalami kenaikan menjadi $56,60 \%$ pada siklus III naik menjadi $64,76 \%$. Siswa LA pada tahap pratindakan ada di angka $13,7 \%$, naik menjadi 35,42 \% pada Siklus I , siklus II Siswa LA kembali naik dengan angka $48,26 \%$ dan pada siklus III naik menjadi $64,24 \%$.

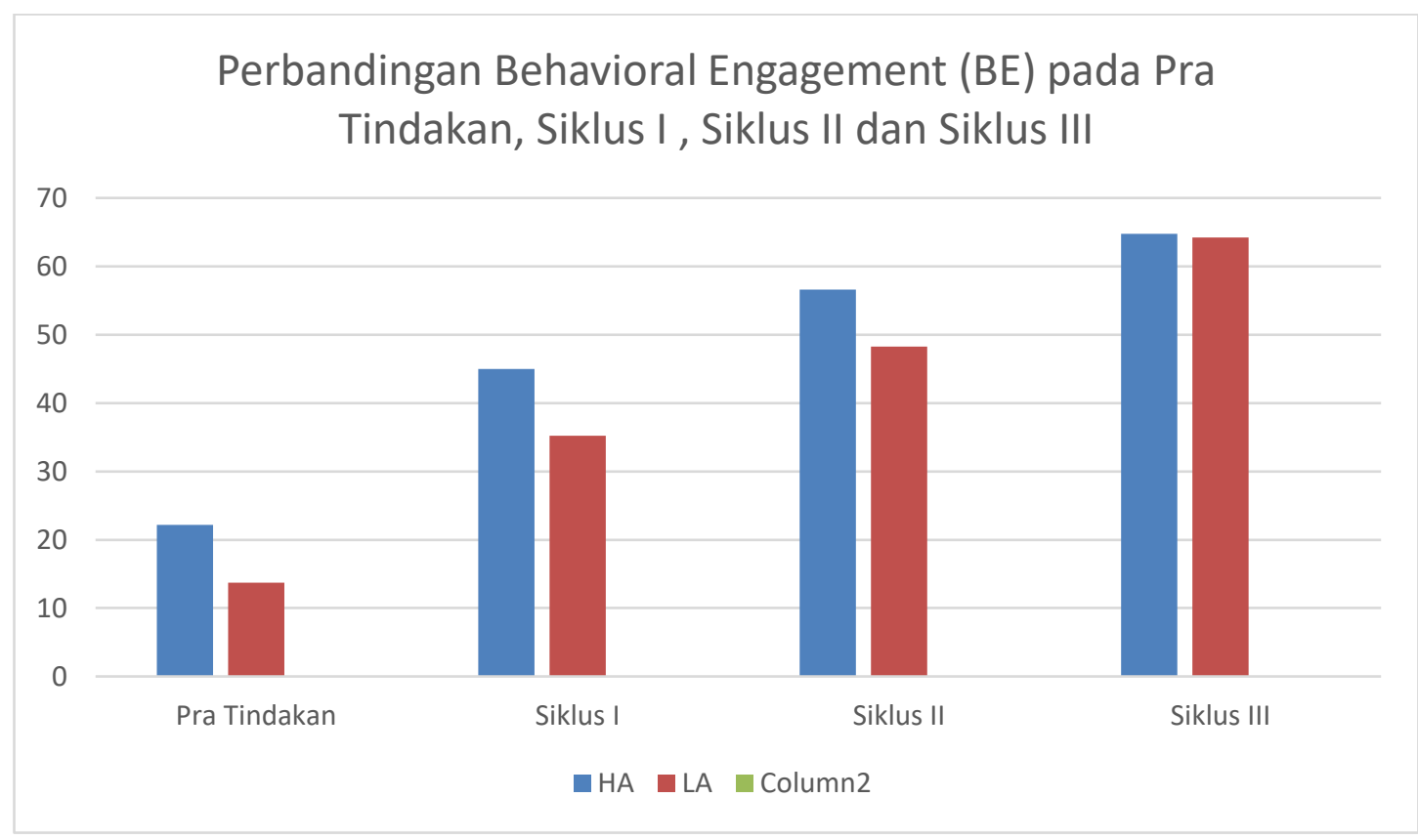

Gambar 5. Perbandingan Behavioral Engagement (BE) pada Pratindakan, Siklus I, Siklus II dan Siklus III.

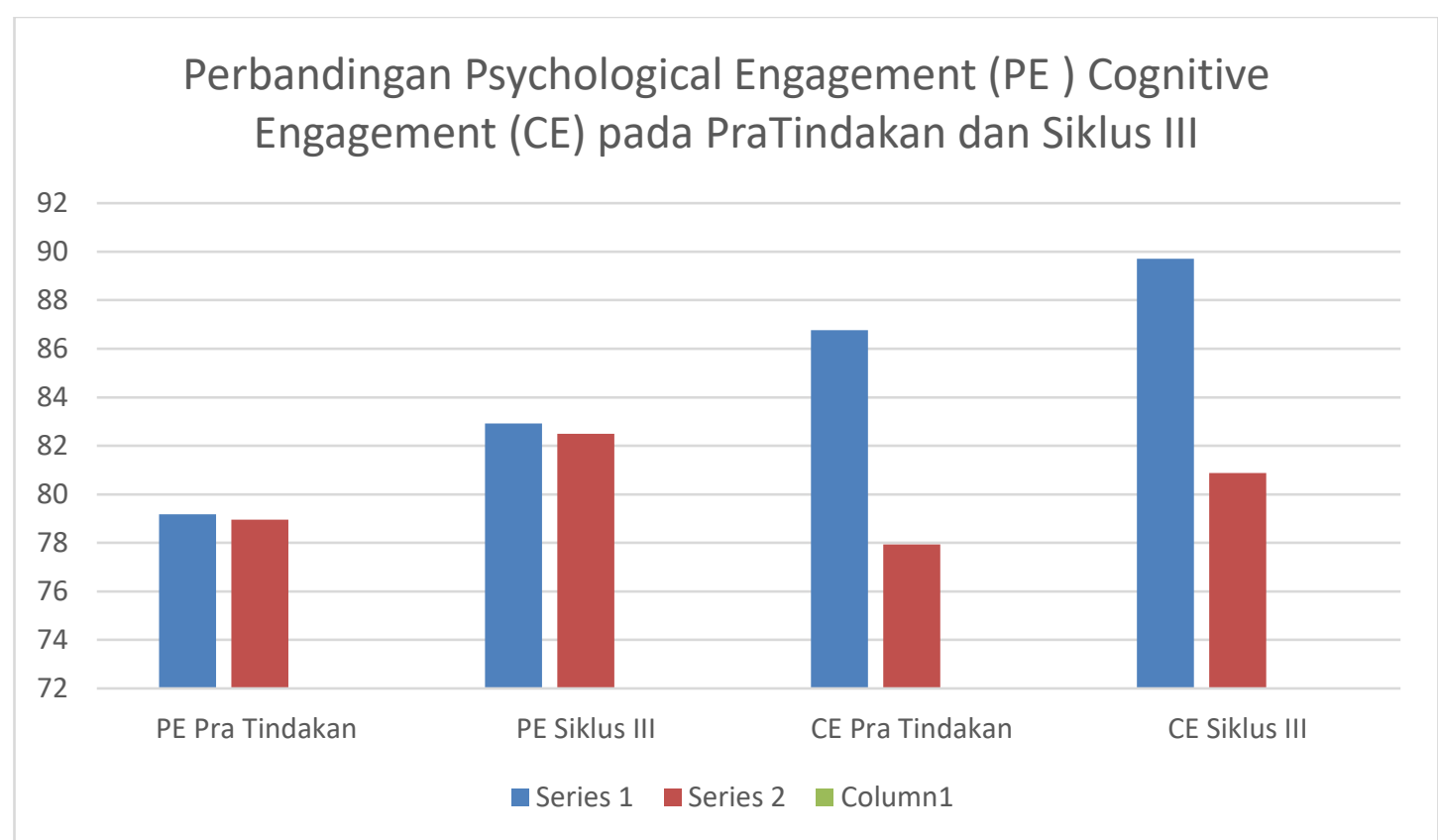

Gambar 6. Perbandingan PE dan CE pada PraTindakan dan Siklus III siswa HA dan LA .

Kedua aspek menunjukan kriteria "Sangat Setuju" baik pada Siswa HA maupun LA, namun dengan perolehan angka yang berbeda PE siswa HA dan LA memperoleh angka yang berbeda . PE siswa HA dan LA memperoleh angka yang hampir sama pada tahap PraTindakan yaitu $79,17 \%$ dan $78.96 \%$. Pada siklus III PE siswa HA dan LA mengalami peningkatan menjadi $82,92 \%$ dan $82,5 \%$. 
CE siswa HA pada PraTindakan ada pada angka 87,76 \% kemudian meningkat menjadi 89,71\% di Siklus III. Siswa LA memperoleh skor CE lebih rendah apabila dibandingkan dengan siswa HA. CE siswa LA pada PraTindakan berada pada angka 77,94\% dan meningkat menjadi $80,88 \%$ pada Siklus III.

Berdasarkan data Observasi PraTindakan pada kelas X Mipa 7 SMA Negeri 1 Garut menunjukan rendahnya keterlibatan siswa (Student's Engagement) di dalam mengikuti pembelajaran Bahasa Inggris. Indikasi rendahnya keterlibatan siswa diketahui berdasarkan hasil Observasi Behavioural Engagement (BE) selama proses pembelajaran.

Rendahnya BE siswa disebabkan oleh pembelajaran di dalam kelas yang belum memfasilitasi siswa untuk terlibat aktif di dalamnya. Pembelajaran belum memberi kesempatan kepada siswa untuk bekerja di dalam kelompok dan saling bertukar informasi satu sama lain. Kegiatan belajar yang terjadi hanya sebatas mendengarkan guru menjelaskan melalui slide PPT. Pembelajaran yang berpusat pada guru bersifat tidak kontekstual. Fokus pembelajaran adalah pada konten, bukan pada proses pembelajaran. Hal ini menyebabkan siswa berperan secara pasif karena pengetahuan ditransfer langsung dari guru kepada siswa dan tugas -tugas diberikan secara individual. (Smit, Brabander ,\& Martens : 2014).

Upaya untuk memperbaiki keterlibatan siswa dalam pembelajaran dilakukan dengan penggunaan media pembelajaran berupa emodul berbasis Discovery learning menunjukan perubahan yang positif pada setiap siklus . Perubahan positif ditunjukan dengan adanya peningkatan rata -rata frekuensi aktifitas siswa pada seluruh aspek yang diamati dalam Behavioral Engagement (BE). Adanya perubahan positif juga ditemukan pada Psychologycal Engagement (PE) dan Cognitive Engagement (CE) berdasarkan angket SEI (Student Engagement instrument ) yang diberikan pada tahap PraTindakan dan Siklus III.

Pembelajaran dengan menggunakan media pembelajaran emodul Interaktif menggunakan metode Discovery Learning pada Siklus I telah meningkatkan keterlibatan siswa apabila dibandingkan dengan keterlibatan siswa pada tahap PraTindakan . Berdasarkan hasil pengamatan selama proses pembelajaran, terdapat siswa yang tidak membaca dan memahami petunjuk penggunaan emodul tersebut, sehingga siswa tersebut kehilangan tahapan pembelajaran Discovery learning yang menjadi métode pada emodul. Pada saat masuk tahap eksplorasi materi pembelajaran, siswa yang tidak mengikuti setiap tahapan /langkah -langkah pembelajaran di emodul menjadi tidak menguasai keterampilan untuk menyusun kalimat dengan menggunakan target bahasa yang diharapkan. Siswa pada setiap siklus pembelajaran menggunakan emodul ini harus senantiasa mengikuti setiap tahapan dalam pembelajaran sebagai pelaksanaan Discovery learning yang ditargetkan. Dalam emodul Interaktif ini, siswa juga mempunyai kesempatan untuk berkolaborasi bersama teman kelompok untuk bersama sama menyelesaikan tugas pada Lembar kerja interaktif secara kolaboratif.

Hasil pelaksanaan Siklus II secara umum menunjukan peningkatan seluruh aspek BE. Siswa HA lebih mempersiapkan diri ketika pembelajaran dan lebih terbiasa untuk mengeksplorasi materi pembelajaran dengan berbagai sumber . Aspek motivasi dan minat untuk menemukan solusi dari permasalahan yang diajukan terkait materi yang sedang dipelajari semakin meningkat terlihat di siklus II.

Pelaksanaan Siklus III menunjukan perubahan positif pada seluruh aspek BE. Pada siklus III pencapaian BE siswa HA dan LA memperoleh hasil yang mirip. Pengelompokan pada siklus III dilakukan dengan mendesign pembelajaran kelompok bersama teman sebaya dalam kolaboratif Learning untuk menyusun Teks Transaksional dengan menggunakan Past Tense vs Present Perfect Tense.

Pembelajaran dengan menggunakan emodul berbasis Discovery Learning dapat mendorong siswa untuk terlibat aktif di dalam pembelajaran. Hasil pengamatan menunjukan perbedaan yang cukup mencolok pada BE pratindakan yang menggunakan métode ceramah dengan hasil Tindakan Siklus I, siklus II dan Siklus III. Hasil ini sejalan dengan Velez (2011) dalam penelitiannya bahwa siswa lebih menikmati pembelajaran dan terlibat secara aktif di 
dalam pembelajaran dengan emodul Interaktif menggunakan metode Discovery learning adalah cara efektif untuk meningkatkan keterlibatan dan partisipasi siswa.

Peningkatan BE siswa LA cenderung lebih tinggi jika dibandingkan dengan siswa HA. Kondisi ini disebabkan karena siswa LA menjadi lebih bersemangat, termotivasi dan memiliki rasa senang untuk belajar. Pembelajaran dengan emodul Interaktif menggunakan metode Discovery learning ini memfasilitasi keterampilan berfikir siswa untuk dapat digunakan dalam menemukan solusi dari permasalahan yang dimunculkan terkait materi Past Tense vs Present Perfect Tense. Media pembelajaran dapat merupakan wahana penyalur pesan dan informasi belajar. Media pembelajaran yang dirancang secara baik akan sangat membantu peserta didik dalam mencerna dan memahami materi pembelajaran.

Peningkatan BE siswa LA cenderung lebih tinggi jika dibandingkan dengan siswa HA. Kondisi ini disebabkan karena siswa LA menjadi lebih bersemangat, termotivasi dan merasa lebih senang untuk belajar. Pemebelajaran dengan eModul berbasis Discovery Learning menyebabkan siswa merasa terpacu semangatnya untuk mempelajari materi ajar dengan baik. Kondisi ini membuat siswa menjadi aktif dan terlibat dalam pembelajaran. Siswa menjadi lebih tertantang untuk memahami materi dengan stimulasi yang diberikan pada eModul, sehingga aktivitas siswa LA menjadi lebih tinggi dari sebelumnya.

BE yang diamati pada penelitian Tindakan Kelas ini meliputi beberapa aspek, yaitu Berbicara (Berbicara dengan guru, berbicara dengan siswa lain di luar kelompok, berbicara dengan kelompok), mendengar (mendengarkan guru, mendengarkan siswa lain di luar kelompok, mendengarkan kelompok) membaca dan menulis. Data BE yang diperoleh merupakan hasil observasi di dalam kelas selama proses pembelajaran berlangsung dengan cara menghitung frekuensi setiap aktivitas pada setiap siklus. Aspek berbicara dalam penelitian ini meliputi berbicara dengan guru, berbicara dengan siswa lain di luar kelompok, dan berbicara dengan kelompok . Aktivitas berbicara yang diamati dapat berupa siswa yang saling berdiskusi dan bertanya mengenai hal-hal yang ada kaitannya dengan materi pembelajaran dan proses pembelajaran.

Berdasarkan hasil pengamatan hasil pengamatan aktivitas berbicara siswa pada siklus I, siklus II, dan siklus III, terjadi peningkatan pada aspek berbicara dengan guru, berbicara dengan siswa lain di luar kelompok, dan berbicara dengan kelompok baik pada siswa HA maupun LA. Peningkatan aspek berbicara pada siswa HA dikarenakan siswa merasa termotivasi utuk mengutarakan pemikirannya terkait materi pelajaran. Aktifitas mengerjakan tugas dalam eModul secara berkelompok memancing rasa ingin tahu siswa. Siswa berusaha bertanya kepada teman ataupun guru mengenai hal-hal yang tidak diketahui. Siswa La tidak sungkan untuk bertanya pada siswa HA.

Aktifitas berbicara siswa LA yang meningkat dapat disebabkan karena siswa merasa lebih nyaman dan leluasa untuk bertanya dan mengungkapkan pendapatnya dengan temannya sendiri. Pusporini (2011) dalam penelitiannya menyatakan bahwa siswa cenderung merasa takut dan tidak berani untuk bertanya atau mengeluarkan pendapatnya kepada guru, tetapi siswa lebih suka mengeluarkan pendapatnya kepada teman sejawatnya atau siswa lain.

Aspek mendengarkan dalam penelitian ini meliputi mendengarkan penjelasan materi mendengarkan guru, mendengarkan siswa lain di luar kelompok, mendengarkan kelompok. Aktifitas mendengarkan yang diamati dapat berupa siswa yang sedang berdiskusi dan mendengarkan pendapat siswa mengenai materi pelajaran yang sedang menjadi bahan diskusi - Hasil observasi menunjukan peningkatan keseluruhan aspek mendengarkan dari tahap praTindakan menuju Siklus I, Siklus II dan Siklus III. Peningkatan aspek mendengarkan disebabkan oleh interaksi yang terjadi antara siswa HA dan LA. Peningkatan aktifitas mendengarkan siswa LA diasumsikan sebagai sumbangan yang diberikan dari siswa HA. Siswa HA memberikan bantuan kepada siswa LA dalam belajar. Hal ini membuat siswa lebih sering bertanya kepada teman dan guru, sehingga aktivitas mendengarkan juga meningkat. Penyelesaian tugas dalam eModul yang menuntut kolaboratif bersama teman kelompok memungkinkan hal tersebut dapat meningkat. 
Aspek membaca mengalami perubahan positif dari Siklus I menuju Siklus III. Pada siklus I , siswa tidak mengalami peningkatan pada aspek membaca , namun dapat meningkat pada siklus selanjutnya. Demikian juga pada siklus III, Pemberian Lembar Kerja Siswa yang terdapat dalam emodul memaksa siswa untuk mencari informasi dari berbagai sumber guna melengkapi LKS. Siswa dapat memanfaatkan gadget dengan baik, untuk mencari informasi di Internet . Pembelajaran yang diterapkan bersifat student centered sehingga siswa harus secara mandiri mencari sumber informasi yang dibutuhkan agar dapat memecahkan masalah. (Usman : 2017).Pembelajaran yang berpusat pada siswa telah terbukti membawa siswa ke tingkat pemikiran kritis yang lebih tinggi, pemecahan masalah dan peningkatan sikap untuk belajar (Overby : 2011).

Aktivitas menulis juga mengalami peningkatan pada setiap siklus. Aktivitas menulis yang diamati adalah menulis di LKS, menulis di buku catatan dan papan tulis. Kegiatan menulis siswa LA meningkat karena siswa dibimbing untuk menemukan konsep-konsep baru di dalam pembelajaran melalui emodul serta LKS yang disematkan dalam emodul. Kegiatan menulis dilakukan siswa ketika memperoleh pengetahuan baru yaitu membantu memperjelas dan menghubungkan ide -ide ilmiah. (Balgopal \& Walace : 2009) .

Psychological Engagement (PE) dan Cognitive Engagement (CE) PE dan CE dianalisis berdasarkan angket SEI (Grier -reed et al : 2021) yang diisi oleh siswa pada tahap PraTindakan dan Siklus III . PE terdiri dari tiga Indikator, yaitu hubungan guru dan siswa, dukungan teman dalam pembelajaran dan dukungan keluarga dalam pembelajaran. Terjadi peningkatan PE dari tahap PraTindakan menuju Siklus III, baik pada siswa HA maupun siswa LA Hasil Analisis angket menunjukan kemiripan hasil PE pada siswa HA dan LA. Kemiripan hasil ini menununjukan bahwa PE pada siswa HA dan LA hampir sama. Hal ini dimungkinkan karena siswa LA dan HA berada dalam satu kelas yang sama sehingga teman -teman yang ada di sekelilingnya sama dan guru yang mengajar juga sama.Baik siswa LA dan HA memiliki perasaan dan hubungan yang sama dengan teman sekelas dan guru. Keterlibatan emosi siswa pada sekolah menunjukan minat, nilai dan emosi emosi terhadap sekolah, misalnya perasaan di kelas, perasaan terhadap sekolah dan guru, perasaan terhadap perlakuan disiplin dan motivasi, perasaan memiliki, perasaan positif, dan menghargai prestasi akademik di sekolah. Keterlibatan siswa pada sekolah merupakan mediator bagi peran kompetensi emosi terhadap prestasi akademik . Semakin tinggi kompetensi emosi siswa, semakin tinggi keterlibatan siswa pada aktivitas akademik sekolah (Dharmayana : 2012).

Selama proses pembelajaran, siswa terlihat lebih bersemangat dan termotivasi untuk belajar apabila dibandingkan saat tahap PraTindakan. Suasana belajar menjadi lebih hidup karena siswa aktif bekerja di dalam kelompok dan bertanya, baik kepada siswa maupun kepada guru. Penggunaan eModul Interaktif menggunakan metode Discovery learning ini, siswa lebih menikmati dan terlibat aktif dalam pembelajaran dengan teman sebaya dibandingkan dengan pembelajaran yang berpusat pada guru. Interaksi positif antara guru dan siswa akan mendukung kebutuhan sosial, emosional dan kognitif siswa. Melalui interaksi yang baik antara guru dengan siswa dapat meningkatkan minat belajar dan kesempatan belajar. Hal ini dikarenakan kesempatan belajar yang yang diberikan oleh guru lebih besar. Guru memberikan dukungan kepada siswa untuk berpartisipasi aktif di dalam pembelajaran (Gregory, Allen \& Mikami : 2014). Penggunaan eModul sebagai media pembelajaran adalah cara yang efektif untuk meningkatkan keterlibatan dan partisipasi siswa, memfasilitasi ligkungan kelas yang hangat dan interaktif . Pembelajaran ini dalam bentuknya yang paling sederhana didefinisikan sebagai suatu proses pemberian stimulus membuat siswa tertantang untuk memahami ,mengeksplorasi, berkolaborasi untuk mencapai target pembelajaran.

CE terdiri dari tiga indikator, yaitu kontrol dan relevansi kerja sekolah, harapan dan tujuan masa depan serta motivasi dari luar peserta didik. CE dapat mengukur sejauh mana siswa berupaya dalam mengerjakan tugas -tugas sekolah yang dihadapi (Mandernach : 2015). CE mengalami peningkatan dari tahap PraTindakan menuju siklus III . Peningkatan terjadi pada siswa maupun siswa LA . Hasil menunjukkan CE siswa HA lebih tinggi daripada CE siswa 
LA . Perbeedaan ini dimungkinkan karena siswa HA memiliki kemampuan kognitif dan BE yang lebih tinggi daripada siswa LA. Siswa yang berprestasi akademik tinggi cenderung memiliki motivasi daya saing yang kuat dibanding dengan siswa yang berprestasi rendah (Latipah : 2010) . Keterlibatan secara emosi memperkuat berkembangnya sikap dan prilaku bersekolah yang positif. Sikap dan prilaku bersekolah yang positif berpengaruh positif terhadap keterlibatan dan komitmen siswa terhadap sekolah. Keterlibatan dan komitmen siswa terhadap aktivitas sekolah dan perkembangan siswa yang positif menyebabkan berkurangnya prilaku beresiko , pada akhirnya secara bersama-sama mempengaruhi keterlibatan kognitif siswa (Dharmayana : 2012).

Sejumlah penelitian menguatkan bahwa siswa yang tidak terlibat dalam pembelajaran merupakan salah satu faktor rendahnya kognitif siswa . Peningkatan keterlibatan prilaku siswa dapat berdampak langsung pada peningkatan pencapaian siswa, semakin banyak siswa yang berpartisipasi aktif dalam kegiatan pembelajaran maka siswa akan semakin memahami isi pembelajaran (Gregory et al : 2014).

\section{KESIMPULAN}

Penggunaan e-Modul Interaktif menggunakan metode Discovery learning pada mata pelajaran Bahasa Inggris materi Past Tense vs Present Perfect Tense untuk meningkatkan performa Akademik siswa yang dilaksanakan dalam tiga siklus menghasilkan peningkatan keterlibatan siswa HA dan siswa LA. Peningkatan keterlibatan siswa terjadi pada Behavioral Engagement (BE), Psychologycal Engagement (PE) dan Cognitive Engagement (CE).

\section{DAFTAR PUSTAKA}

Balgopal,M.M, \& Wallace , A.M. (2009) . Decisions and Dilemmas ; Using writing to Learn Activities to Increase Ecological Literacy, Journal of Environmental Education, (June 2016 )

Dharmayana,W.(2012).Keterlibatan Siswa (Student Engagement )sebagai mediator Kompetensi Emosi dan Prestasi Akademik .jurnal Psikologi, 76 - 94.

Fadly (2014). Wawasan Pembelajaran dalam Perspektif Al Qur'an .Jurnal Study Islam.Volume 3 No 1.

Faidah, Siti. (2015). Pengembangan Bahan Ajar Berbasis E-book Menggunakan Kvisoft Flipbook Maker untuk Kelas VIII MTS N 2 Kota Cirebon (Doctoral dissertation, IAIN Syekh Nurjati).Furrer,C.J, Skinner ,E.A \& Pitzer ,J.R (2014) The Influence of Teacher and Peer relationship on students Classroom Engagenment and everyday motivational Resilience.

Fitriani, Irma, and Suci Rohayati. "Pengembangan E-Book Berbasis Android Dengan Pendekatan Saintifik Pada Mata Pelajaran Administrasi Pajak Kelas Xii Akuntansi Di Smk Negeri 2 Buduran." Jurnal Pendidikan Akuntansi (JPAK) 7.1 (2019).

Gregory, A, allen ,J \& Mikami A. (2014); Effects of A Professional development Programo n Behavioral Engagement of Student in Middle and high School. Psychology in the Schools.

Grier-reed,T,Appleton ,J, Rodriguez, M, Ganuza, Z \& Reschly, A.L ( 2012). Exploring the students Engagement instrument and Career perceptions with College Students,2(2) 85 96.https : doi.org/10.5539/jedp.v2n2

Khotib , Anwar .2014. Pengembangan bahan ajar matematika berbasis penemuan terbimbing Materi Lingkaran untuk SMP Kelas kelas VIII. Skripsi. Tidak diterbitkan.Cirebon : IAIN Syekh Nurjati.

Latipah (2010). Strategi Self Regulated learning dan prestasi Belajar : Jurnal Psikologi ,37 (1). Mandernach , B.J. (2015) Assessment of students Engagement in Higher education : A Synthesis of literature and Assessment Tools. International Journal Of learning , Teaching and Educational Research, 12 (2), 1 - 14.

Nurhayati ,Eti.2011.Psikologi Pendidikan inovatif. Yogyakarta : Pustaka Pelajar. 
Pusporini, N (2011) Penerapan model pembelajaran Tutor sebaya pada Mata pelajaran Sosiologi . jurnal komunitas, 3 (1). 103 - 120.

Ridwan, 2013 Belajar mudah penelitian untuk guru -Karyawan dan peneliti muda . Bandung. alfabet.

Smith .K. Barbander .C.J.De \& Martens, R.L. (2014) Students-centred and Learning-centred learning environment in pre-vocational secondary education : Psychological needs, and motivation . Scandinavian journal of educational Research, 58 (6) 695 - 712.

Teodorese , Adriana 2015 “ Mobile learning and it's impact on Business english learning Procedia-Social and Behavioral Sciences 180 pp $1535-1540$ (https /www.sciencedirect.com/science/article/ pii/1877042815016493, Diakses pada tanggal 15 Januari 2021.

Trianto .2015. Mendesain Model pembelajaran Inovatif, Progresif dan Kontekstual . Jakarta : Kencana Prenada Media Grup.

Usman .R. (2017) Penggunaan tutor sebaya dan Aktivitas siswa untuk meningkatkan Hasil Belajar Pokok Bahasan analisis Isi Pidato Siswa Kelas VIII SMP Negeri 2 Tapung FKIP Universitas Terbuka UPBJJ-UT, Pekanbaru-5, 16-27.

Velez, J.J. (2011) Cultivating through Peer teaching Journal of agricultural Education. .52 (1).

Wilujeng, I., \& Mulyaningsih, S. (2013). Pengembangan media e-book interaktif melalui strategi mind mapping pada materi pokok listrik dinamis untuk SMA kelas X. Inovasi Pendidikan Fisika, 2(2). 